\title{
Influence of social responsibility of the enterprise on the individual labor mobility
}

\author{
Olga Zolotaryova \\ Ph.D., Associate Professor of Department of finances and credit, \\ Dneprodzerzhinsk State Technical University, Ukraine \\ E-mail address: zolotaryova@ukr.net
}

\begin{abstract}
Keywords: social responsibility, enterprise, individual labor mobility, workers, tools, influence,
\end{abstract} strategy, development

\begin{abstract}
The main purpose of the article to justify the need to consider the influence of social responsibility of the enterprise on individual labor mobility and the prospects of using the tools of social responsibility for the formation of positive trends in individual labor mobility and ensuring the development of the enterprise. In the article the essence of the category of "social responsibility" is defined, the foreign and domestic experience in the field of social responsibility is investigated, the main strategic objectives and tools of social responsibility of the enterprise in different countries are considered. Statistical data on the labor market in Ukraine over the past five years are shown, which pointing negative trends in individual labor mobility. Proposals for greater use of the tools of social responsibility of the company and changing these trends are made. Problems faced by the enterprise on the path to this are concretized. The State's role in removing these barriers is explaned.
\end{abstract}

\section{INTRODUCTION}

Economic and political crisis in Ukraine actualized the need of the formation and development of social responsibility and enhance its positive influence on individual labor mobility. Unprecedented social differentiation, low wages, stable inflation, shifting the burden of the crisis on the shoulders of ordinary citizens, curtailment of social transfers and deterioration the level of quality of life is the result of social irresponsibility of the business, the state and public organizations. Their reluctance and unwillingness in a critical situation to give preference to socially important interests and objectives instead corporate priorities leads to the marginalization of the population, the formation of a passive consciousness and depressive moods, deactivate essential powers, lack of desire and financial opportunities for development and training, reducing productivity, falling interest in the results of the company, slowing down the process of development and innovation. All this is accompanied by a high turnover of workers who are often looking not just a new job, but the opportunity to go abroad, where much better working and living conditions, and ultimately leads to the outflow of personnel from the country and the growth of social tension in society.

Overcoming these phenomena can be facilitated by the active implementation and development of the most important social responsibility - social responsibility of enterprises, which corresponds to the new level of development of society and is a concept that integrates national strategy, common human values and ethical behavior of business organizations. So today most of the world are involved in the development and implementation of corporate social responsibility in the workplace.

Ukraine also tries don't stay out of these processes. However, it should be noted that the concept of social responsibility in Ukraine is in a stage of formation. Management of domestic businesses only comes to awareness of the fact that the best way to ensure their sustainable development - is, first of all, establishing relationships with employees on the principles of social responsibility.

The main reason that motivates the enterprises Ukraine today to pay special attention to social responsibility to employees - a "war for talent", because all depends on staff and on the effective management of the company and gives the ability to improve its results in the short and the long run. 


\section{RESEARCH THEORETICAL LITERATURE}

The issue of corporate social responsibility, social ethics and corporate social programs paid attention in their works Ansoff I., F. Herzberg, D. Kotler, D. Mooney, E. Mayo, M. Meskon, V. Ouchi, T. Peters, A. Fayolle, F. Hedouri.

In recent years, national scientists pay increasing attention to study the problems of social responsibility. Thus, consideration of principles of corporate social responsibility are devoted papers of Amosha A., B. Bayura, I. Bulyeyev, M. Butko, A. Hohul A. Zinchenko, A. Kolot, I. Kudinov, I. Lebedev, N. Saprykin, A. Sokhatska, N. Suprun. Problems of social responsibility as a part of social policy are studied on the practice by such scholars as O. Bilous, V. Bilous, V. Twin, I. Hnybidenko, T. Zajac, V. Kutsenko, E. Libanova, O. Novikova, L. Shevchuk, B. Yarovaya.

However, require more attention question about the tools of social responsibility influencing on individual labor mobility, which in turn can be as positive or negative factor of influencing the success of the enterprise.

\section{RESEARCH RESULTS}

Today the category of "social responsibility" is not completely defined. Her research is at the intersection of theoretical and methodological, methodical and practical issues within the various social sciences that could not be reflected in the wording of the essence of this phenomenon.

For the first time the term "corporate social responsibility" was introduced in a scientific revolution in the 50's of last century American scientists who also interpreted the ambiguous nature of the concept. For example, M. Friedman believed that entrepreneurs implementation in practice of socially responsible activities are robbing owners (shareholders) as a result of additional costs in areas that do not belong to the professional competence of enterprises. Instead, another American professor T. Bosch underlines the mandatory social orientation of the company, because society allows enterprises to realize themselves and get profits [1].

In economic literature, the term "social responsibility" is often interpreted as the responsible attitude of the enterprise to its product (services), consumers, employees, shareholders, partners and active social position, is in harmonious coexistence, cooperation and constant dialogue with representatives of the administration, the commercial sector and society stakeholders in order to facilitate effective decision acute economic, social, humanitarian and environmental problems [2-9].

According to the World Council for Sustainable Development Companies, social responsibility of the company is a company's long-term commitment to behave ethically and contribute to economic development while improving the quality of life of workers and their families, communities and society as a whole.

By definition, the European Commission ("Green Paper on Corporate Social Responsibility", 2001), corporate social responsibility is "a concept whereby companies integrate social and environmental issues into their commercial activities on a voluntary basis."

Interestingly definition $\mathrm{V}$. Nusinov, by which social responsibility of business is implemented across corporate management in some type of social commitments (mostly voluntary) to employees, partners, government, civil society and the society as a whole [10].

By definition V. Dubnytskiy, "social responsibility of the company" - it is the responsibility of those who make a business decision, for those whom directly or indirectly these decisions touches. It encourages companies to take into account the interests of society by taking responsibility for the impact on consumers of the company, staff, communities and the environment in all aspects of its activity [11].

Generalized interpretation of the concept of corporate social responsibility includes: corporate ethics; corporate social policy on society; corporate policy on environmental protection; principles and approaches to corporate governance and corporate behavior; conditions, opportunities, guarantees respect for human rights (including equal opportunities for men and 
women, persons with special social needs, for different age groups) in relations with partners, suppliers, customers and staff.

The idea of social responsibility of enterprises has become a finished look a few decades ago when the World Economic Forum in Davos, UN Secretary General Kofi Annan appealed to the leaders of the world's largest companies to join an international initiative - the Global Compact, in which the conditions for business cooperation with institutions UN, trade unions, non-governmental organizations to implement the general principles of social equity and environmental protection. Based on the preference of joint action, the Global Compact has set a target of the principles of social responsibility, and ensure its participation in solving burning problems.

Extensive branching directions of socially responsible business models defined in:

American model - characterized by voluntary initiatives in the financing of various projects and programs, charity, patronage, sponsorship; This activity is encouraged by society and the State (that is, companies that are actively involved in social programs, are exempted from a number of taxes enshrined in law);

European model - differs from the American in that business social activity regulated by the state; so that it is recognized covert form of corporate social responsibility;

British model - a combination of American and European models; namely, as in the US model is available in a large active companies implement their own social programs; signs of the European model are shown in the active state support of business;

Japanese model - more focused on the internal environment and is based on a system of "lifetime employment" (Table 1).

Table 1. Strategic objectives and priority instruments the most famous models of social responsibility of enterprises

\begin{tabular}{|c|c|c|c|}
\hline Country & $\begin{array}{c}\text { Model of social } \\
\text { responsibility of } \\
\text { the enterprise }\end{array}$ & Strategic purposes & $\begin{array}{c}\text { Tools of social responsibility } \\
\text { of the enterprise }\end{array}$ \\
\hline USA & Amarican & $\begin{array}{c}\text { - improvement of the environment; } \\
\text { - the development of society; } \\
\text { - the development of staff; } \\
\text { - improving the economy }\end{array}$ & $\begin{array}{c}\text { - corporate communications; } \\
\text { - social investment; } \\
\text { - social partnership }\end{array}$ \\
\hline $\begin{array}{c}\text { Countries of } \\
\text { European }\end{array}$ & European & $\begin{array}{c}\text { - the development of society; } \\
\text { - the development of staff; } \\
\text { - improvement of the environment; } \\
\text { - improving the economy }\end{array}$ & $\begin{array}{c}\text { - corporate communications } \\
\text { - social partnership; }\end{array}$ \\
\hline $\begin{array}{c}\text { Asian } \\
\text { Countries }\end{array}$ & Asian & $\begin{array}{c}\text { - the development of staff; } \\
\text { - - improve the environment }\end{array}$ & $\begin{array}{c}\text { - corporate communications } \\
\text { - social investment; }\end{array}$ \\
\hline Ukraine & National & $\begin{array}{c}\text { - the develonomial partnership; } \\
\text { - the development of staff }\end{array}$ & $\begin{array}{c}\text { - corporate communications; } \\
\text { - social partnership; }\end{array}$ \\
\hline
\end{tabular}

Comparative analysis of models of social responsibility of enterprises in different countries proves the existence of significant differences between domestic practice social responsibility and international experience in this field. Thus, among the strategic objectives of the national model of personnel development is in last place and there is no purpose to improve the environment. Among the priority instruments in last place - social investment. But not paying much attention in the implementation of corporate social responsibility is personnel automatically lead to non-powerful 
motivational potential of social responsibility and a lack of understanding of the importance and the impact of individual tools on labor mobility. Consequently, there is low interest in improving the performance of the enterprise, there are negative trends in individual labor mobility of staff, chief of which is the increase in turnover and falling productivity.

The individual labor mobility is a conscious and deliberate legitimate need, temporal transformation of motivation, contents and process components activities, professional and human gegrafichnih position, which is implemented as a result of the revitalization and development of the essential powers of the individual, and responding to the impact of regulatory institutional mechanism (in this article focuses on the impact of the enterprise and more precisely instruments of its social responsibility) through the choice of forms and directions of mobility.

Today the situation in the labor market is difficult in Ukraine [12]. It is obvious that, first, the number of economically active working-age population over the past five years is constantly decreasing, including occupied (Table 2).

Table 2. Dynamics of economically active and employed population of Ukraine in 2010-2014

\begin{tabular}{|c|c|c|c|c|}
\hline \multirow{2}{*}{ Years } & $\begin{array}{c}\text { The economically active population } \\
\text { of working age }\end{array}$ & \multicolumn{2}{|c|}{$\begin{array}{c}\text { Including busy working age population } \\
\text { in \% of the } \\
\text { thousand people } \\
\text { population in the } \\
\text { corresponding } \\
\text { age group }\end{array}$} & $\begin{array}{c}\text { average, } \\
\text { in \% of the } \\
\text { thousand people } \\
\text { population in the } \\
\text { corresponding } \\
\text { age group }\end{array}$ \\
\hline 2010 & 19164,0 & 71,9 & 17451,5 & 65,5 \\
\hline 2011 & 19181,7 & 72,6 & 17520,8 & 66,3 \\
\hline 2012 & 19317,8 & 72,9 & 17728,6 & 66,9 \\
\hline 2013 & 19399,7 & 72,9 & 17889,4 & 67,3 \\
\hline 2014 & 19035,2 & 71,4 & 17188,1 & 64,5 \\
\hline
\end{tabular}

Second, the reduced average number of full-time employees, the rate of labor turnover reception. Real average wages in 2014 also decreased dramatically (Table 3). In such conditions, when there are negative trends in individual labor mobility, actualized the need in the implementation and development of instruments of social responsibility before company employees.

Table 3. Dynamics of average number of full-time employees, turnover ratio of labor and real average wages in Ukraine 2010-2014

\begin{tabular}{|c|c|c|c|c|}
\hline \multirow{3}{*}{ Years } & \multirow{3}{*}{$\begin{array}{l}\text { The average } \\
\text { number of full- } \\
\text { time employees, } \\
\text { thousand people }\end{array}$} & \multicolumn{2}{|c|}{ Labor turnover ratio } & \multirow{3}{*}{$\begin{array}{c}\text { Real average } \\
\text { monthly wage } \\
\text { in } \% \text { to previous } \\
\text { year }\end{array}$} \\
\hline & & reception & release & \\
\hline & & \multicolumn{2}{|c|}{$\begin{array}{l}\text { in } \% \text { of the average number of full- } \\
\text { time employees }\end{array}$} & \\
\hline 2010 & 10262 & 25,0 & 27,7 & 110,2 \\
\hline 2011 & 10083 & 28,3 & 30,5 & 108,7 \\
\hline 2012 & 10123 & 26,1 & 29,9 & 114,4 \\
\hline 2013 & 9720 & 26,6 & 30,3 & 108,2 \\
\hline 2014 & 8959 & 22,8 & 30,3 & 93,5 \\
\hline
\end{tabular}

Clearly the influence of social responsibility of enterprises on individual labor mobility can be displayed using Figure 1.

It should be emphasized that implementing the social responsibility of employers, first, try without breaking the laws and regulations of state regulation, increase profits and to achieve economic purposes; Secondly, they must take into account the human and social aspects during of their business [13]. 


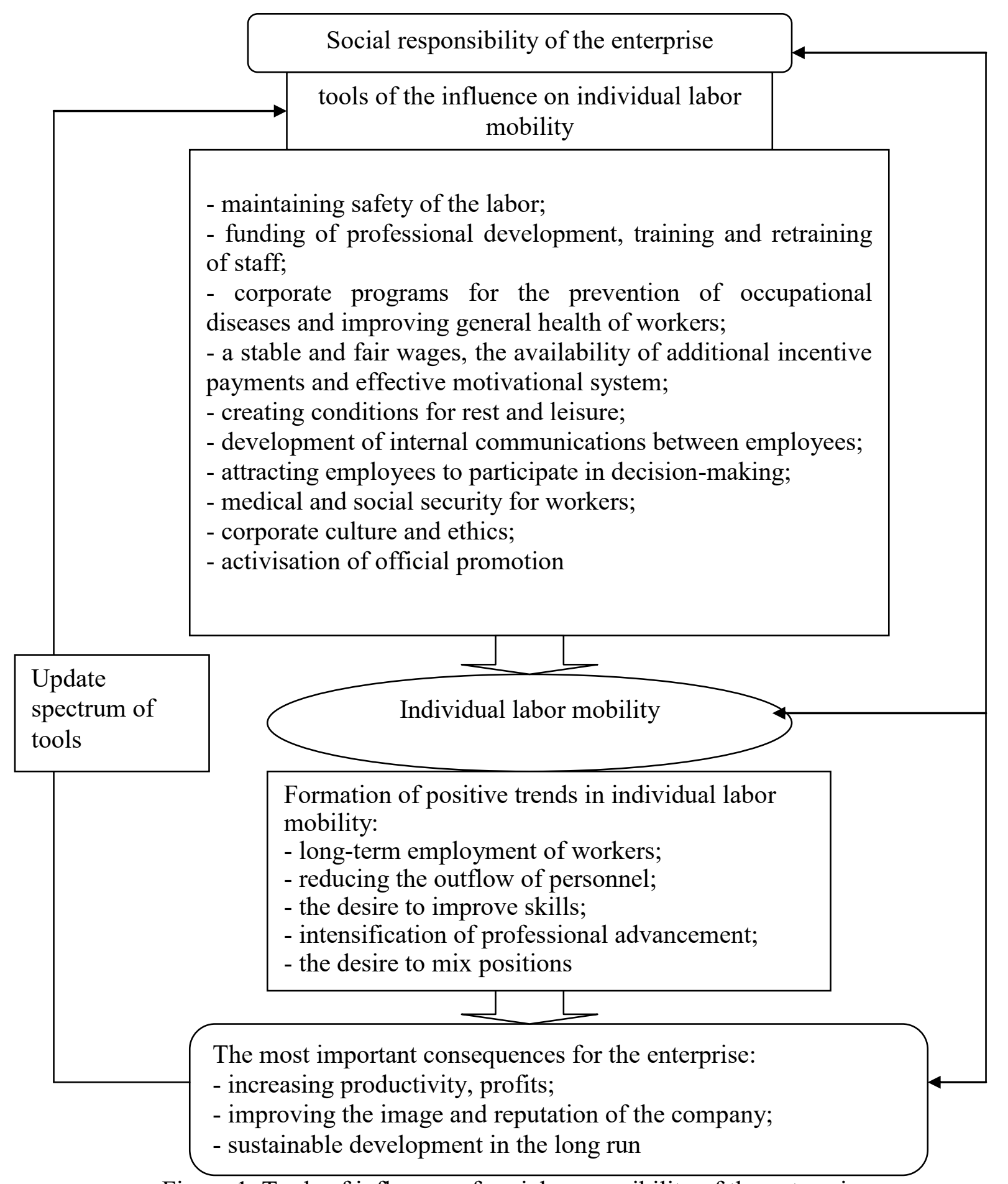

Figure 1. Tools of influence of social responsibility of the enterprise on individual labor mobility

The most important economic and social benefits of socially responsible companies, as is proved by the practice of foreign and domestic companies are: long-term consolidation of employees, reducing the turnover of the workforce, enhancing product competitiveness, securing commitment of employees ideology corporation, enhancing the status of the corporation in society, creating an ethical system of relations within the corporation .

So important reasons for the use of instruments of social responsibility regarding selfemployment for the management of mobility following: staff development to avoid staff turnover, to attract the best professionals in the market who want to get a promising job; productivity growth in the company; improving the company's image and reputation; stability and sustainability in the 
long term; the ability to attract investment capital for socially responsible companies is higher than for other companies; preserving social stability in society.

The enterprise must constantly improving the management system of social responsibility with a view to ultimate intended effect. Managing social responsibility of the company is a system by which decisions are made and implemented. Objectives and policies of social responsibility have defined by owners and members of the workforce.

The company must provide employees the opportunity to choose their own representative to interact with senior management on issues of social responsibility and participate in internal controls over the implementation of social responsibility policy of the company.

Implementation of internal control over the implementation of policies of social responsibility of enterprises allows: identify problems and evaluate this area for forecasting their impact; define a set of resources that can now be focused on socially responsible activities; develop ways to improve the current situation, evaluate and select the most effective of them; make their implementation using the current system of internal control; provide the implementation of the decisions; establishing active feedback from stakeholders.

Enterprises of Ukraine has already begun to voluntarily implement international standard SAI SA 8000: 2001 "Social responsibility» (SAI - SOCIAL ACCOUNTABILITY INTERNATIONAL - International NGO "Social Responsibility", founded in 1987).

But it should be emphasized in Ukraine there are still many obstacles that can eliminate by the state and objectively hinder the development of social responsibility:

- imperfection of Ukrainian legislation regarding business development, providing the opportunity to avoid any responsibility;

- insufficient support for the development of the domestic business of the state, lack of proper regulation tools, support and promotion is corporate social responsibility;

- unstable economic and political situation in the country, the periodic crises that destroy reached, forcing the company to change business priorities and just survive;

- in Ukraine are just beginning to set up social institutional structures, which are aimed at the development and implementation of the principles of corporate social responsibility;

- low level of small and medium business, which hasn't, as previously indicated, the necessary maturity to understand and implement the tools of social responsibility;

- a significant share of domestic business is shady and therefore unlikely we can talk about the social responsibility of the business to the community if the laws are violated;

- greater activity requires the development of vocational training in the area of social responsibility;

- low level of business culture the main actors of the market.

But, like any progressive idea that the concept of social responsibility, despite the obstacles and difficulties, continue their way to Ukrainian realities, as evidenced by domestic business experience in this field.

The peculiarity of Ukrainian reality is that the development of business does not meet the modern requirements of its conduct, as evidenced by the presence of many factors that hinder the spread of the theory and practice of social responsibility. Therefore, business entities, and the state should aim to overcome existing obstacles. First of all, it concerns the improvement of legislation regulating the activities of businesses in general, and social responsibility, in particular, the formation of effective instruments of support and stimulation [14].

On the part of domestic business entities need an understanding of the fact that social responsibility is part of their strategic development and must be systematic, transparent and not seen as charity. Being certified to international standards, any line of business, we should really meet them. This will ensure sustainable economic development of present and future.

It should be emphasized that the overall direction and content of social responsibility in Ukraine are different from the West, primarily the fact that the vast majority of businesses considering the issue in a purely legal context. Unlike "voluntary" Western approach. 
As the study, actively bearing the idea of social responsibility in the practice of Ukrainian economy the foreign companies with offices in Ukraine (company "Ernst \& Young", which is a global leader in auditing and consulting, corporation "Microsoft"- the worldwide leader in software development, the American cosmetic company "Mary Kay", the company "Nestle" - the largest food manufacturer in the world market). This large Ukrainian company of international level ("Nemiroff" - the first Ukrainian alcohol brand that has official international status; PJSC "DSS" an international company manufacturing steel products, "Interpipe" - an international company that is among the ten largest manufacturers of metal products). A large proportion - a joint venture with foreign investments ("British American Tobacco Ukraine", Ukraine-Austrian company LLC "Fisher-Mukachevo" et al.). Ukrainian national company operating on the domestic market ("Lyuksoptika" - Ukrainian national network optician, "DTEK" - Energy Company of Ukraine energy company OJSC "Prykarpattyaoblenergo", the plant "Fiolent" et al.) [15].

In the vast majority - a large private company, the number of employees is measured as much as possible - tens of thousands of employees (280 thousand people - "Nestle"; 140 thousand "Ernst \& Young", 80 thousand - "Intel" and others), minimum - 2-6 thousand people (3 thousand OJSC "Prykarpattyaoblenergo", 5 thousand -" Galnaftogaz "; 6 thousand - PJSC "DSS"). Among the projects implemented by them in recent years and was successful, effective, given basic directions of social responsibility, it should be noted those who were associated with an investment in staff in ensuring proper working conditions, health, training and professional growth.

At the same time, experts on social responsibility believe that it is the privilege not only of large corporations with millions of profits, and is an objective necessity, "rule of life" of the enterprise, which is part of the development strategy regardless of your budget. Thus, despite the fact that the nature and scope of its activities a significant proportion of small and medium business objectively limited in their commitment to growth (household, service, hotel, restaurant service), and their main goal, staying within size their business to be successful, but it does not rule out active work in the sphere of social responsibility rather the contrary.

\section{CONCLUSION}

Most employers today recognize the fact that staff performance depends not only on the professionalism and competence of staff, but also from how they relate to the work. High levels of satisfaction and loyalty motivates employees more to quality and timely execution of the work, thereby increasing the productivity of enterprises and contributing to the achievement of its strategic objectives. Reducing the level of satisfaction and loyalty of staff conversely, inhibits the development of the enterprise, reduces the effectiveness of employees and increases the probability of outflow of personnel from the company. It is therefore important to recognize the first signs of negative changes and take appropriate measures to remedy the situation in the sphere of individual labor mobility.

In view of the above, the actual implementation of the enterprise for a system of monitoring staff satisfaction and loyalty as the most efficient way to look at themselves through the eyes of company employees and understand how employees perceive change and innovation; how employees are satisfied with working conditions and job content; what kind of problems and difficulties exist in relations with management and staff colleagues; tools of social responsibility of the enterprise are able to motivate employees to perform better, to intensify the development of essential powers and remain in the enterprise.

The ratio of staff to their work depends on several factors, which combine to determine the degree of satisfaction and loyalty of staff. There are six key factors that influence satisfaction and loyalty personnel: relationship with colleagues and management; the content and nature of the work; relation to the values and culture of the company; pay and benefits; perception changes; training and development.

To assess the satisfaction and loyalty of staff in the monitoring system personnel active advisable to use a technique «SSM» (Smart Satisfaction Monitoring), which is described in studies of modern specialists in management. Questionnaire «SSM» allows to obtain accurate and reliable 
information about the level of satisfaction and loyalty of employees on six key factors. The information allows management company promptly identify "problem areas" in the management of staff and to take adequate measures to improve the effectiveness, satisfaction and loyalty of employees [16].

A key component of socially responsible enterprises is the modern ethic of social and labor relations. It's not that management should be more "democratic" with respect to its workers. It is as before may seek to increase economic benefits, but to achieve this, it is necessary to use tools of social responsibility of the enterprise that allow workers to unite. Corporate ethics of industrial relations is possible under certain conditions, when: plant manager understands the growing role of social function, which is reflected in the precise mission of the company; all employees of the company directly interested in the final result of its business; allocation of business results based on the principle of mutual and voluntary consent "Do ut des" - "I give, that you gave me."

In other words, the company's management is willing to pay much more, provided that the work is highly skilled and efficient. The experience of developed market economies suggests that such conditions already exist in many enterprises, which are called social.

These enterprises is the example of positive trends in individual labor mobility, such as: consolidation of workers; reducing the outflow of personnel; desire training; activation of professional advancement; desire to professional advancement. The most important achievement implications of these trends for the enterprise: increased productivity, profits; improving the image and reputation of the company; sustainable development in the long term.

So, hard to overestimate the influence of tools of social responsibility of the enterprise on individual labor mobility (of employees): maintaining safety of the labor; funding for professional development, training and retraining of personnel; corporate programs for the prevention of occupational diseases and improving general health of workers; stable and fair wages, the availability of additional incentive payments and effective the motivational system; creating conditions for rest and leisure; supporting internal communications between employees; attracting employees to participate in decision-making; social insurance of employees; corporate culture and ethics; activisation of official promotion.

It should be emphasized that the general trend in developed countries is to support social responsibility of the state, development of national programs, standards and evaluation criteria of social responsibility of companies, the existence of different forms of institutionalization of social responsibility of the enterprise [17]. Unlike developed countries, in Ukraine there is poorly developed institutional environment, there are no special regulatory laws on social responsibility. This demonstrates the need to adapt international experience to the conditions of Ukrainian enterprises.

\section{References}

[1] A. Belyenka Implementation Information about social responsibility in Ukraine, [electronic resource]., access: http://feu.kneu.edu.ua/ua/confere_nce/conf_social_dev_ukr_12/section5/belenka/

[2] A. Grishnova, Social Responsibility: the nature, value, strategic directions of development in Ukraine, Ukraine: aspects of labor, No 7, 2010, pp. 3-8.

[3] A.I. Amosha, Responsibility of corporations to the development of small business in the context of modernization strategy of industrial cities, Bulletin of Donetsk State University of Management "Manager", No 3(65), 2013, pp. 9-20.

[4] A. M. Kolot, Corporate social responsibility: the evolution and development of theoretical views, Economics, No 4, pp. 5-27.

[5] A.M. Kolot, OA Grishnova, Social Responsibility: Theory and Practice Development: monograph, Kyiv National Economic University, Kiev, 2012, 501 p. 
[6] D. Bayura, Corporate social responsibility in the corporate governance, Ukraine: aspects of labor, No 1, 2009, pp. 21-25.

[7] M. Butko, Genesis of social responsibility and its formation in Ukraine, Finance of Ukraine, No 8, 2010, pp. 74-84.

[8] M. A. Saprykina, Corporate social responsibility: models and management practice, practice activities, edited by A. Redkin, Type-in "Dark Leaf", Kiev, 2011, 480 p.

[9] N.A. Suprun, Corporate social responsibility as a factor of sustainable development, The economic practice, No 4, 2013, pp. 61-74.

[10] B.J. Nusinok, A.V Yarovaya, Corporate Social Responsibility: background tanovlennya and rozvytokv Ukraine, Social responsibility of government, business and citizens: monograph: in 2 t., eds. GG Pivnyak, NSU, Dnepropetrovsk, Vol.1, 2014, pp. 306-309.

[11] V.I. Dubnytskiy, V.V Collar, N.M Chupryna, Corporate social responsibility in koteksti of public-private partnership, Social responsibility of government, business and citizens: monograph: in 2 t., eds. GG Pivnyak, Dnepropetrovsk, Vol.1, 2014, pp. 74-87.

[12] The official website of the State Statistics Service of Ukraine, [electronic resource], access: http://www.ukrstat.gov.ua/operativ/operativ2007/rp/ean/ean_u/osp_rik_b_07u.htm

[13] A.M. Kolot, O.A Grishnova, O.A Gerasimenko, Socialization of labor relations in the context of sustainable development: monographet, Kyiv National Economic University, Kyiv, 2010, $192 \mathrm{p}$.

[14] N.I. Kobzar, V.F. Levchenko, A.I Kiriyenko, Theory and practice of corporate social responsibility in Ukraine, Social responsibility of government, business and citizens: monograph: in 2 t., eds. GG Pivnyak, Dnepropetrovsk, Vol.1, 2014, pp. 112-120.

[15] V.I. Lebedev, Corporate Social Responsibility concept and model for Ukraine. Ukraine: aspects of labor, No 5, 2014, pp.13-19.

[16] O.V. Zybareva, L.A. Gombe, Monitoring of satisfaction and staff loyalty as the basis of modern enterprise system transformation stimulate his, [electronic resource], access: http://www.rusnauka.com/18_DNI_2010/Economics / 68889.doc.htm

[17] Sh. M. Valitov, V.A. Maligin, Interaction and power business. Essence, new forms, trends, social responsibility, Economics, Moscow, 2009, 207 p. 